\title{
Reply to: a letter to the editors: Re: minimally invasive oesophagectomy: current status and future direction
}

\author{
Muhammed Ashraf Memon • Nick Butler • \\ Stuart Collins $\cdot$ Breda Memon
}

Received: 29 October 2011/Accepted: 8 December 2011/Published online: 5 April 2012

(C) Springer Science+Business Media, LLC 2012

We thank Maas et al. for their letter regarding our review article [1] of minimally invasive oesophagectomy for cancer published in Surgical Endoscopy. We also thank them for agreeing with the content of our paper, which is very encouraging.

The omission of Scheepers et al.'s paper [2] is regrettable, the inclusion of which would have been useful for readers.

We are looking forward to the results of the TIME trial [3], which will provide useful information regarding the differences when performing oesophagectomy via open

This reply in on behalf of Nick Butler (Department of Surgery, Ipswich General Hospital, Ipswich, QLD 4305), Stuart Collins (Department of Surgery, Ipswich General Hospital, Ipswich, QLD 4305) and Breda Memon (Department of Surgery, Ipswich General Hospital, Ipswich, QLD 4305).

M. A. Memon $(\bowtie) \cdot$ N. Butler $\cdot$ S. Collins $\cdot$ B. Memon Department of Surgery, Ipswich General Hospital, Ipswich, QLD 4305, Australia

e-mail: mmemon@yahoo.com

\section{A. Memon}

Sunnybank Obesity Centre, Suite 9, McCullough Centre, 259 McCullough Street, Sunnybank, Ipswich, QLD 4109, Australia

\section{A. Memon}

Department of Surgery, University of Queensland, Brisbane, QLD, Australia

\section{A. Memon}

Faculty of Health Sciences and Medicine, Bond University, Gold Coast, QLD, Australia

\section{A. Memon}

Faculty of Health and Social Sciences, Bolton University,

Bolton, Lancashire, UK transthoracic versus minimally invasive transthoracic approach. I think this trial is long overdue.

Disclosures Dr M. A. Memon, Dr N. Butler, Dr S. Collins and Mrs B. Memon have no conflicts of interest or financial ties to disclose.

\section{References}

1. Butler N, Collins S, Memon B, Memon MA (2011) Current status of minimal access surgery for oesophagus. Surg Endosc 35(4): 473-487

2. Scheepers JJG, Veenhof AAFA, van der Peet DL, van Groeningen C, Mulder C, Meijer S, Cuesta MA (2008) Laparoscopic transhiatal resection for malignancies of the distal oesophagus. Outcome of the first 50 resected patients. Surgery 143(2):278-285

3. Biere SS, Mass KW, Bonavina L, Garcia JR, van Berge Henegouwen MI, Rosman C, de Lange ES, Bonjer HJ, Cuesta MA, van der Peet DL (2011) Traditional invasive vs minimally invasive oesophagectomy: a multicentre, randomized trial (TIMEtrial). BMC Surg 11(1):2 